\title{
Peranan Lingkungan Sosial Terhadap Pembentukan Sikap Peduli Lingkungan Peserta Didik Di MAS Al-Islam Petala Bumi
} Muslim $^{1}$, Almegi $^{2}$, Alfiah ${ }^{4}$, Akmal $^{4}$ dan Hutri Rizki Amelia ${ }^{5}$

\author{
1,2,3,4 Program Pendidikan Geografi, Universitas Islam Negeri Sultan Syarif Kasim Riau \\ ${ }^{5}$ Program Pendidikan Geografi, STKIP Pesisir Selatan \\ e-mail: mulim@,uin-suska.ac.id
}

\begin{abstract}
ABSTRAK. Peranan lingkungan sosial memiliki peranan penting terhadap pembentukan sikap peduli lingkungan peserta didik. Adapun lingkungan sosial yaitu lingkungan keluarga, madrasah masyarakat. Penelitian ini bertujuan untuk mengetahui peranan lingkungan keluarga, madrasah, dan masyarakat terhadap pembentukan sikap peduli lingkungan peserta didik di MAS AL ISLAM . Penelitian ini menggunakan metode penelitian survey. Sampel penelitian berjumlah 100 peserta didik. Instrumen dalam penelitian ini berupa kuesioner, studi literatur, dan studi dokumentasi. Analisis data menggunakan analisis regresi linear ganda. Hasil penelitian menunjukan bahwa lingkungan keluarga, madrasah, dan masyarakat memberikan peranan yang berarti dan lingkungan masyarakat yang berperan paling tinggi terhadap pembentukan sikap peduli lingkungan peserta didik.
\end{abstract}

Kata kunci: Lingkungan Sosial, Sikap Peduli Lingkungan.

\section{PENDAHULUAN}

Sikap peduli lingkungan dalam kehidupan sehari-hari bermasyarakat diartikan sebagai reaksi sesorang terhadap lingkungannya, dengan tidak merusak lingkungan alam. Dengan sikap peduli lingkungan maka akan tercipta lingkungan yang bersih dan asri. Menurut Sue (2003:

43) menjelaskan bahwa "peduli lingkungan menyatakan sikap-sikap umum terhadap kualitas lingkungan yang diwujudkan dalam kesediaan diri untuk menyatakan aksi-aksi yang dapat meningkatkan dan memelihara kualitas lingkungan dalam setiap prilaku yang berhubungan dengan lingkungan”. Bila sikap peduli lingkungan dapat dinyatakan dengan aksi-aksi, maka peserta didik yang peduli akan lingkungan- nya akan senantiasa menjaga kelestarian lingkungan.

Dalam pembelajaran geografi setiap pembahasan materi apapun, senantiasa dijelaskan dengan menggunakan perspektifkelingkungan, kewilayahan, dan komplek keruangan, Sudarma (2011: 59) dan dengan geografi ini diharapkan peserta didik mampu meminimalisir prilakuprilaku yang masih belum peka terhadap ling- kungan sekitarnya, dan diharapkan peserta didik lebih paham dalam kmemanfaatkan, mengelola ruang/lingkungan dengan bijaksana. Geografi sangat erat kaitannya dengan lingkungan. Seperti diungkapkan Sala (2011: 1) yaitu:

Geography is defined as an environtmental science that studies the interactions between the geosphere and its components with the biosphere and the anthroposphere. Geography stresses integration and interdependence between these spheres. In this sense it serve as a bridge between natural science and social science diciplines, with particular emphasis on studying the conditions required to support human life. Although geography's wide embrace may be seen as one of it's weaknesses, it is also a strength and an attraction.

Berdasarkan fungsi mata pelajaran geografi jelas bahwa pembelajaran Geografi di tingkat MA harus mampu menumbuh- kan sikap siswa yang sadar dan peduli terhadap lingkungan. Pembentukan karakter siswa bukan hanya terjadi di dalam kelas/madrasah saja, bahwa lingkungan masyarakat/teman sebaya terutama keluarga juga berperan dalam pembentukan 
karakter. Pola pen- didikan di keluarga yang turut berpengaruh pada kondisi siswa di madrasah menjadi tugas bagi guru dan segenap warga madrasah dalam mendidik karakter siswa. Lingkungan keluarga yang mampu menerapkan kedisiplinan turut berdampak pada kedisiplinan siswa di Madrasah. Perihal disiplin waktu, seorang anak yang biasa di rumah bangun pagi nanti di madrasah juga mudah untuk berangkat ke madrasah dan tidak terlambat madrasah. Begitupun dalam hal disiplin mengenakan pakaian seragam akan terlihat rapi dan sesuai dengan peraturan di Madrasah. Selain keluarga, lingkungan sesama teman juga turut berpengaruh pada perkembangan siswa. Teman yang sehari-hari berinteraksi dapat memberikan pengaruh positif maupun negatif. Apabila lingkungan yang dipilih ini mengarah pada peningkatan kualitas diri maka nantinya akan menjadi manusia yang baik juga.

Menurut Sumaatmadja (1988: 50) "lingkungan sosal terdiri dari kelompok manusia sendiri". Lingkungan sosial menurut Purwanto (2009: 73) ialah "Semua orang atau manusia lain yang mem- pengaruhi kita, baik secara langsung maupun tidak langsung". Ditekankan pula oleh Setiadi dan Kolip (2011: 181) yang dimaksud dengan lingkungan sosial adalah "Tempat atau suasana dimana sekelompok orang merasa sebagai anggotanya, seperti lingkungan kerja, lingkungan RT, ling- kungan pendidikan, lingkungan pesantren, dan sebagainya". Jadi lingkungan sosial adalah semua orang dan suasana tempat yang dapat mempengaruhi kita baik secara langsung maupun tidak langsung.

Pendidikan diyakini sebagai salah satu bidang yang memiliki peran penting dan strategis dalam pembangunan suatu bangsa Ningrum (2009: 1). Ditambahkan pula oleh Yulifar (2009: 25) bahwa kegiatan pendidikan sebagai realitas sosial yang keberadaannya sering diharapkan sebagai agen pembaharuan dalam berbagai sekmen kehidupan masyarakat. Proses pendidikan selalu terjadi dalam suatu lingkungan yang sering disebut dengan lingkungan pendi- dikan. Sebagaimana menurut Sukmadinata (2003:5) "Di dalam lingkungan ini mencakup lingkungan fisik, sosial intelek- tual, dan nilai-nilai". Lingkungan fisik sendiri terdiri atas lingkungan alam dan buatan manusia yang menjadi tempat sekaligus pendukung atau penghambat bagi berlangsungnya proses pendidikan. Contohnya seperti sarana, prasarana dan fasilitas fisik yang ada.

Kata "sikap peduli lingkungan" dalam kehidupan bermasyarakat lebih kental diartikan sebagai reaksi peduli seseorang terhadap lingkungannya. Misal- nya, tidak merusak lingkungan alam dengan selalu menjaga pelestarian ling- kungan, atau dengan kata lain harus selalu menjaga dan melestarikan lingkungan agar tidak menjadi rusak, tercemar bahkan menjadi punah. Dengan sikap peduli lingkungan maka akan tercipta yang bersih dan asri. Namun gambaran sikap peduli lingkungan dewasa ini, terasa semakin banyak diabaikan. Orang-orang lebih banyak mementingkan kehidupannya sendiri, sehingga terlena dan akhirnya lari dengan sikap peduli lingkungan. Kondisi seperti ini lebih tampak pada kehidupan masyarakat di kota-kota besar, yang pada umumnya sibuk dengan diri sendiri.

Berdasarkan latar belakang di atas dan dengan melakukan pengamatan sementara secara singkat oleh penulis di tingkat MAS Al Islam, masih banyak peserta didik yang belum begitu peduli akan lingkungan. Beberapa contoh yang penulis temukan yaitu masih banyak peserta didik yang membuang sampah sembarangan dan membiarkan tergeletak dimana saja, vandalisme, pengrusakan lingkungan, jajan sembarang- an, masih banyaknya brosur yang ditanam di batang pohon-pohon dekat madrasah, tidak harmonisnya hubungan sesama teman, serta tidak ada kesadaran untuk menjaga lingkungan dari peserta didik. Hal tersebut bisa terjadi karena disebabkan oleh beberapa faktor diantaranya adalah peranan dari lingkungan sosial peserta didik itu sendiri. Oleh sebab itu maka penulis dalam penelitian ini mengambil rumusan masalah 1) Bagaimana peranan lingkungan keluarga terhadap pembentuk- an sikap peduli lingkungan peserta didik MAS Al Islam Petala Bumi? 2) Bagai- mana peranan lingkungan madrasah terhadap pembentukan sikap peduli lingkungan peserta didik MAS Al Islam 
Petala Bumi 3) Bagaimana peranan lingkungan masyarakat/teman sebaya terhadap pembentukan sikap peduli lingkungan peserta didik MAS Al Islam Petala Bumi?.

Tujuan penelitian adalah: 1) Untuk menganalisis peranan lingkungan keluarga terhadap pembentukan sikap pedulilingkungan pada peserta didik MAS Al-Islam Petala Bumi, 2) Untuk menganalisis peranan lingkungan sekolah terhadap pembentukan sikap peduli lingkungan pada peserta didik MAS Al-Islam Petala Bumi dan 3) Untuk menganalisis peranan lingkungan masyarakat terhadap pembentukan sikap peduli lingkungan pada peserta didik MAS Al-Islam Petala Bumi.

Hasil penelitian ini diharapkan 1) dapat menambah wawasan pengetahuan terhadap dunia pendidikan terkait peran lingkungan sosial terhadap pembentukan sikap peduli lingkungan. 2) diharapkan dapat bermanfaat bagi peneliti yang akan melakukan penelitian yang serupa, serta instansi pendidikan sebagai patokan dalam pembelajaran geografi secara umum. 3) diharapkan dapat membentuk peserta didik untuk selalu sadar akan pentingnya sikap peduli lingkungan. 4) Dalam diantaranya penerimaan dari suatu objek lingkungan itu sendiri, partisipasi yang dilakukan peserta didik baik di lingkungan keluarga, madrasah dan masyarakat, penilaian/penentuan sikap, berorganisasi, dan pembentukan karakter atau pola hidup.

\section{METODE}

Penelitian ini menggunakan metode penelitian survey, data yang dikumpulkan melalui individu atau sampel fisik tertentu dengan tujuan agar dapat menggenerali- sasikan terhadap apa yang diteliti. Data- data penelitian ini diperoleh menggunakan kuesioner/angket. Penelitian ini menggu- nakan pendekatan kuantitatif.

\section{HASIL DAN PEMBAHASAN}

Peserta didik dalam menjalani kehidupannya sehari-hari pasti menyesu- aikan diri dengan lingkungan sekitarnya. Purwanto (2009) berpendapat bahwa menyesuaikan diri itu berarti mengubah diri sesuai dengan keadaan lingkungan (penyesuaian diri autoplastis) dan mengubah lingkungan sesuai dengan kehendak atau keiginan diri pribadi (penyesuaian diri alloplastis). Pada umum- nya, setiap individu menggunakan kedua cara tersebut baik dalam usaha mengembangkan dirinya maupun dalam interaksi dengan lingkungannya. Sikap peduli lingkungan peserta didik tidak serta merta timbul begitu saja tanpa ada usaha dari diri dan lingkungan sosial mereka dalam pembentukannya. Dalam penelitian ini terdapat tiga hasil penelitian yang telah dilakukan pada 100 peserta didik MA Al-Islam Petala Bumi.

\section{Lingkungan Keluarga}

Instrumen yang digunakan dalam mengukur peranan lingkungan keluarga terhadap pembentukan karakter sikap peduli lingkungan peserta didik dapat dilihat dari beberapa aspek indicator. diantaranya penerimaan dari suatu objek lingkungan itu sendiri, partisipasi yang dilakukan peserta didik baik di lingkungan keluarga, madrasah dan masyarakat, penilaian/penentuan sikap, berorganisasi, dan pembentukan karakter atau pola hidup.

Berdasarkan perhitungan skor, diperoleh nilai maksimum sebesar 49 dan nilai minimum sebesar 33 dengan range atau selisih sebesar 16. Dari 100 orang responden diperoleh skor rerata (mean)sebesar 42,32, nilai tengah (median) sebesar 43,00, skor yang sering muncul (mode) 45,00, dan standar deviasi sebesar 3.601.

Berikut disusun dalam tabel mengenai distribusi frekuensi peranan lingkungan keluarga yang dibagi menjadi beberapa kelas interval, dan untuk melihat sebaran frekuensi tersebut digambarkan melalui histogram frekuensi pada gambar 


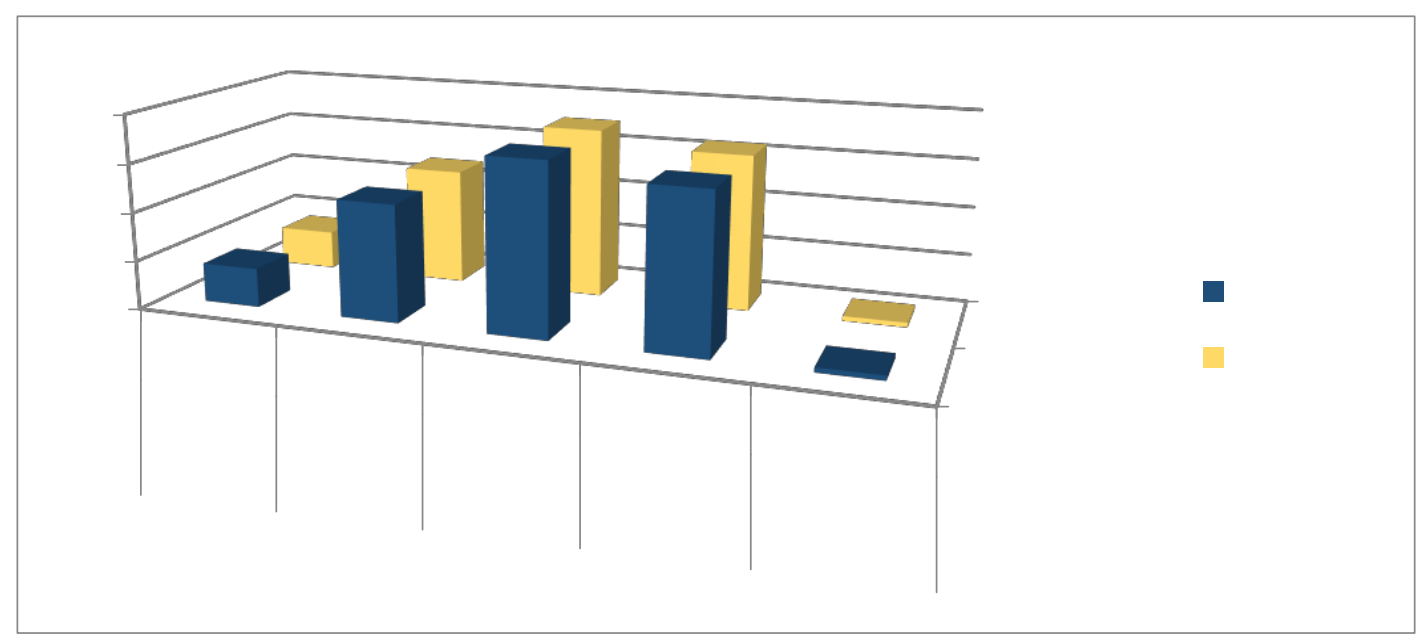

Gambar 1. Histogram Distribusi Frekuensi Peranan Lingkungan Keluarga terhadap Pembentukan Karakter Sikap Peduli Lingkungan Peserta Didik

Dari hasil analisis data yang diperoleh dengan parameter peranan lingkungan keluarga terhadap pembentukan karakter sikap peduli lingkungan peserta didik, diketahui terdapat frekuensi rendah dan sangat rendah. Jika merujuk pada indikator peranan lingkungan keluarga, penanaman nilai-nilai keagamaan dalam kehidupan sehari-hari responden dengan tingkat frekuensi sangat rendah dan rendah ini di dalam keluarga sangat kurang, hal ini disebabkan karena pengawasan dan pendidikan agama dari kedua orang tua responden yang jarang bisa membagi waktunya dikarenakan bekerja, sehingga pengawasan dan pendidikan agama tidak bisa diawasi tiap waktu.

Pola asuh atau cara didik orang tua dalam pembentukan jati diri responden sudah cukup baik, karena orang tua responden mempunyai tingkat pendidikan yang cukup (MA, D1, D3, S1, S2 ). Sama hal nya dengan aturan- aturan dalam lingkungan keluarga sudah cukup baik, karena tingat pendidikan orang tua dan pemahaman orang tua terhadap aturan-aturan di dalam keluarga sangat baik, hal ini dapat dilihat dari sikap responden yang mematuhi aturan untuk tidak keluar hingga larut malam. Interaksi antar keluarga sangat kurang, dikarenakan kedua orang tua yang bekerja, sehingga intensitas waktu untuk berkomunikasi sangat minim, dapat dilihat dari sikap responden yang jarang sekali menolong atau saling membantu dalam mengerjakan PR $\mathrm{kakak} /$ adik di rumah.

Penanaman nilai- nilai dan etika di dalam keluaga cukup baik dikarenakan tingkat pendidikan orang tua yang tinggi sehingga mampu membimbing dan mengajarkan tata krama terhadap responden, contohnya dengan tidak memanggil nama kepada orang yang lebih tua dan tidak egois dan selalu meng- hormati anggota keluarga lain dengan tidak menyalakan TV atau radio dengan volume yang keras. Lalu dalam gambar terdapat tingkat frekuensi sedang, tinggi, dan sangat tinggi. Jika merujuk pada indikator peranan lingkungan keluarga, penanaman nilai-nilai keagamaan dalam kehidupan sehari-hari responden dengan tingkat frekuensi sedang, tinggi, dan sangat tinggi ini di dalam keluarga sangat bagus hal ini disebabkan karena pengawasan dan pendidikan agama dari kedua orang tua responden yang bisa membagi waktunya dikarenakan kedua orang tua memiliki banyak waktu di rumah, ada yang orang tua nya wiraswasta, ada juga yang ayah nya bekerja, tetapi ibu nya tidak, sehingga pengawasan dan pendidikan agama bisa diawasi tiap waktu.

Pola asuh atau cara didik orang tua dalam pembentukan jati diri responden sudah cukup bagus, karena orang tua responden mempunyai tingkat pendidikan yang cukup (MA, D1, D3, S1, S2 ). Sama hal nya dengan aturan-aturan dalam lingkungan keluarga sudah cukup bagus, karena tingat pendidikan orang tua dan pemahaman orang tua terhadap aturan-aturan di dalam keluarga sangat bagus. Interaksi antar keluarga juga sangat bagus, dikarenakan kedua orang 
tua atau salah satu nya yang berada terus di rumah, sehingga intensitas waktu untuk berkomunikasi sangat baik. Penanaman nilai-nilai dan etika di dalam keluaga cukup baik dikarenakan tingkat pendi- dikan orang tua yang tinggi sehingga mampu membimbing dan mengajarkan tata krama terhadap responden. Dari hasil analisis data yang dihasil- kan diambil kesimpulan bahwa lingkungan keluarga memberikan peranan yang berarti terhadap pembentukan karakter sikap peduli lingkungan.

\section{Lingkungan Madrasah}

Sama halnya dengan penyusunan instrumen pada variabel lingkungan keluarga, lingkungan madrasah pun disusun berdasarkan beberapa indikator yang dianggap dapat dijadikan tolak ukur untuk mengetahui peranan lingkungan sekolah terhadap pembentukan karakter sikap peduli lingkungan peserta didik, dianta- ranya adalah guru memberikan arahan dan pengetahuan tentang kesehatan lingkung- an, Sikap guru dalam pembentukan karakter peserta didik, sportif dalam segala hal, pengembangan aspek intelektual dan emosi peserta didik dalam dimensi kemanusiannya, sikap peserta didik terhadap guru (etika), gaya hidup teman- teman madrasah, hubungan peserta didik dengan peserta didik lainnya, penanaman nilai-nilai kedisiplinan dan motivasi.

Dari beberapa indikator tersebut kemudian disusun menjadi beberapa item dalam instrumen, di mana masing-masing item tersebut yang telah diolah dan diperoleh hasil skor minimum sebesar 26, skor maksimum sebesar 50 dengan (range) sebesar 24. Rerata yang berasal dari 100 responden sebesar 42,66, (median) 43,00, (mode) sebesar 45,00 dan nilai standar deviasi adalah sebesar 4.176. Untuk mengetahui frekuensi skor yang diperoleh setiap responden, maka disusun dalam sebuah tabel yang sebelumnya telah diperhitungkan jumlah kelas dan panjang intervalnya terlebih dahulu, kemudian dari hasil penyususnan tersebut dibuatlah diagram untuk melihat sebaran frekuensi- nya. Sebagaimana yang terdapat dalam histogram gambar 2.

Dari hasil analisis data yang diperoleh dengan parameter peranan lingkungan sekolah terhadap pembentukan karakter sikap peduli lingkungan peserta didik, diketahui terdapat frekuensi rendah dan sangat rendah. Jika merujuk pada indikator peranan lingkungan madrasah, guru memberikan arahan dan pengetahuan tentang kesehatan lingkungan dengan sangat baik pada responden dengan tingkat frekuensi sangat rendah dan rendah ini, dikarenakan guru sudah mempunyai kompetensi yang sangat bagus dan memahami materi dengan mendalam. Sikap guru dalam pembentukan karakter peserta didik responden pun sudah bagus, karena sebagian besar guru yang mengajar di tempat penelitian merupakan guru yang senior dan berpengalaman. Ketika dalam lingkungan madrasah, responden cukup sportif dalam segala hal yang ada di sekolah cotohnya adalah berlaku jujur, meskipun terkadang masih berbuat kecurangan saat ulangan. Pengembangan aspek intelektual peserta didik di sini cenderung kurang, dikarenakan tingkat penerimaan responden yang berbeda-beda. Sikap peserta didik terhadap guru (etika) kurang baik ketika di dalam kelas, contohnya sering mengobrol, tidak memperhatikan, bahkan terkadang tidur di dalam kelas pada saat guru sedang mengajar. Gaya hidup temanteman sekolah yang cenderung negatif sebagian besar diikuti oleh responden. Hubungan peserta didik dengan peserta didik lainnya sangat bagus dan rasa kekeluargaan pun sangat tinggi. Penanaman nilai-nilai kedisiplinan dan motivasi di madrasah kurang bisa diterapkan oleh responden dengan tingkat frekuensi sangat rendah dan rendah ini, masih banyak pelanggaranpeanggaran yang dilakukan, contohnya dalam hal kerapihan dan disiplin waktu 


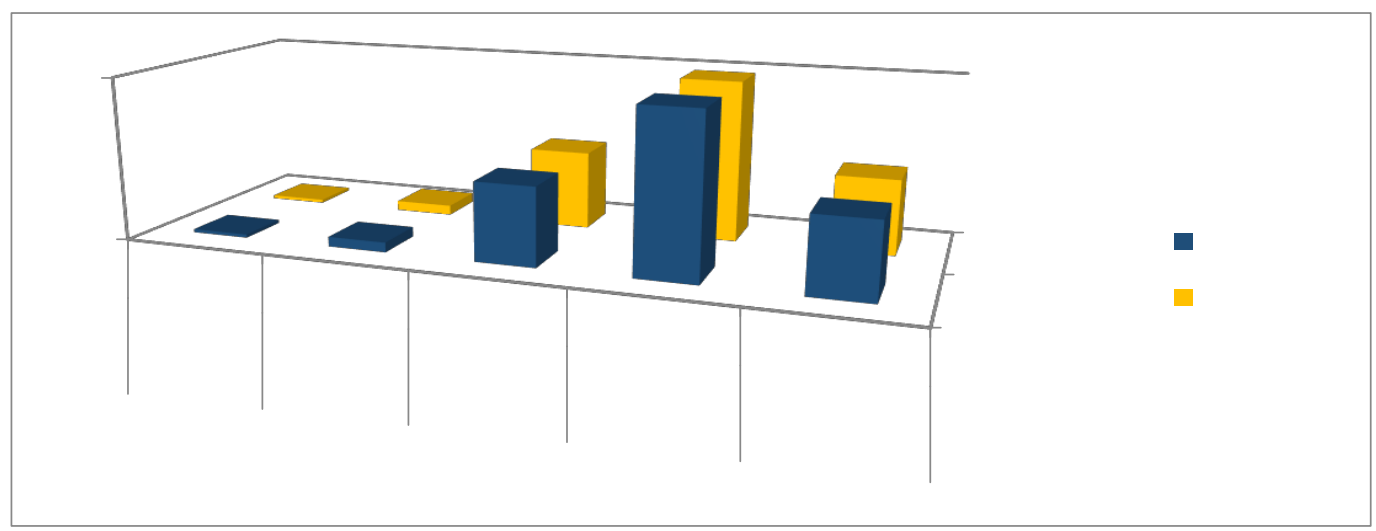

Gambar 2. Histogram Distribusi Frekuensi Peranan Lingkungan Madrasah terhadap Pembentukan Karakter Sikap Peduli Lingkungan Peserta Didik

Lalu dalam gambar terdapat tingkat frekuensi sedang, tinggi, dan sangat tinggi. Jika merujuk pada indikator peranan lingkungan masyarakat, sikap ingin selalu membantu sesama di lingkungan masya- rakat responden dengan tingkat frekuensi sedang, tinggi, dan sangat tinggi cukup bagus, hal ini dapat dilihat dari seringnya responden mengikuti gotong royong yang ada di lingkungan masyarakat dan membantu dalam penggalangan dana yang ada di masyarakat.

Sikap menghargai perbedaan di dalam masyarakat juga sangat baik, karena seringnya responden dengan tingkat frekuensi sedang, tinggi, dan sangat tinggi cukup mendapatkan pengajaran di madrasah dan di rumah. Contohnya dengan tidak menghardik teman/tetangga yang berbeda agama dan selalu mengecilkan volume radio/TV ketika adzan ataupun teman/tetangga yang sedang melakukan ibadah. Sikap dan perilaku untuk melaksanakan tugas dan kewajiban responden dengan tingkat frekuensi sedang, tinggi, dan sangat tinggi di dalam masyarakat masih sudah cukup bagus. Contohnya responden sering menolong tetangga yang sedang susah, hal ini dikarenakan tingkat simpati dan empati responden sangat baik dan peka terhadap sesama.

Penanaman sikap peduli terhadap lingkungan di masyarakat responden dengan tingkat frekuensi sedang, tinggi, dan sangat tinggi sudah cukup bagus. Sifat egois yang dimiliki responden dapat dikalahkan dengan rasa kebersamaan dan kekeluargaan yang tinggi sehingga lebih mementingkan kepentingan bersama daripada kepentingan sendiri. Penerapan hidup sederhana di lingkungan masyarakat responden dengan tingkat frekuensi sedang, tinggi, dan sangat tinggi pun sering dilakukan. Sosialisasi dengan lingkungan sekitar dengan cara menjaga kebersihan lingkungan sudah dilakukan dan diaplika- sikan oleh responden dengan tingkat frekuensi sedang, tinggi, dan sangat tinggi, karena responden sering mendapatkan pengajaran tentang pentingnya lingkungan sekitar atau lingkungan hidup.

Hasil analisis statistik variable independen diketahui bahwa lingkungan masyarakat memberikan pengaruh yang tinggi sama halnya dengan lingkungan keluarga dan madrasah bahwa peranan lingkungan masyarakat pun berpengaruh tinggi terhadap pembentukan karakter sikap peduli lingkungan peserta didik.

\section{Sikap Peduli Lingkungan Peserta Didik}

Demikian pula dengan penyusunan instrument sikap peduli lingkungan peserta didik $(\mathrm{Y})$ tiap item yang termuat dalam instrument penelitian didasarkan pada indikator-indikator yang dianggap dapat mewakili sikap peduli lingkungan peserta didik itu sendiri, dimana indikatorindikator yang ditetapkan diambil dari beberapa teori yang kemudian digabung- kan. Adapun indikator-indikator yang dimaksud di sini antara lain, Receiving (penerimaan): peserta didik memiliki kesadaran untuk membersihkan ruangan kelas jika ruangan tersebut kotor, peserta didik mengaplikasikan di rumah tentang reboisasi yang diterima di sekolah, peserta didik menerima arahan atau nasihat dari kedua orang tua mengenai sadar lingkungan, peserta didik turut andil 
dalam membersihkan sungai di sekitar tempat tinggal, peserta didik selalu bertanya kepada guru/orang tua di rumah ketika ada hal yang kurang jelas mengenai hal-hal yang berkaitan dengan lingkungan, peserta didik sadar atau tahu bahwa air yang tergenang dapat menimbulkan banyak penyakit.

Responding (partisipasi): Peserta didik mampu berinteraksi dengan teman sebaya, guru, dan anggota sekolah lainnya, peserta didik tidak dating terlambat ke sekolah, peserta didik selalu mengikuti kegiatan upacara hari Senin, peserta didik mengikuti kegiatan piket di kelas, bekerja sama atau diskusi dalam mengerjakan tugas yang diperintahkan guru, dan menjenguk ketika ada teman yang sedang sakit. Valuing (penilaian/penentuan sikap): Peserta didk menyukai pembelajaran geografi, atau pembelajaran yang berkaitan dengan lingkungan, peserta didik selalu bersikap ramah kepada teman sebaya, guru, dan anggota sekolah lainnya, peserta didik selalu memanfaatkanan madding sekolah untuk memberikan penjelasan tentang lingkungan, peserta didik berhak menegur teman jika teman tersebut membuang sampah tidak pada tempatnya, peserta didik menyukai kelas yang bersih dan rapi, menolak ajakan teman untuk jajan di warung ketika sedang ada operasi bersih di sekolah.

Organization (organisasi): Peserta didik mengetahui tentang organisasi WWF (World Wild Federation), peserta didik mengikuti organisasi atau kegiatan eskul yang bertemakan lingkungan, peserta didik ikut berpartisipasi jika ada organisasi dari luar madrasah yang bertemakan lingkungan datang ke madrasah, bertang- gung jawab atas kedudukan atau peran di organisasi yang sudah dijalani, menyusun kegiatan piket secara bersama-sama, toleransi dalam membuat suatu keputusan dan mersikap menghargai pendapat orang lain. Characteritazion (pembentukan karakter atau pola hidup): Melakukan sarapan sebelum berangkat ke madrasah, mempersiapkan keperluan madrasah sendiri, jika jarak madrasah dekat, lebih baik menggunakan sepeda atau jalan kaki, sebelum berangkat madrasah peserta didik mencium tangan kedua orang tua, sepulang madrasah, tidak keluyuran melainkan langsung pulang ke rumah, terbiasa dengan tidak mencontek ketika ujian sedang berlangsung. Berdasarkan hasil perhitungan skor tiap item dalam instrument yang dibagikan kepada 100 responden, diperoleh skor maksimum sebesar 150, skor minimum sebesar 104 dengan (range) sebesar 46. Diketahui pula skor rerata yaitu 129,120 (median) 132,00, dan standar deviasi sebesar 10.337. Adapun distribusi frekuensi dan sebarannya secara keseluruhan dari sikap peduli lingkungan peserta didik dapat dilihat pada gambar 4.

Berdasarkan hasil analisis sikap peduli lingkungan peserta didik, diketahui bahwa sikap-sikap yang dimiliki atau yang sudah mulai tertanam dalam diri peserta didik lebih banyak dipengaruhi lingkungan sekolah, walaupun pada kenyataannya lingkungan keluarga dan lingkungan masyarakat pun berperan tinggi. Sebagai- mana diketahui bahwa lingkungan madrasah yang berperan sangat tinggi tidak lepas dari peran guru di madrasah dibandingkan dengan orang tua dan anggota masyarakat.

Melihat kenyataan hasil penelitian bahwa ketiga lingkungan sosial yang paling berperan yaitu lingkungan madrasah dapat diharapkan para pengajar dapat terus meningkatkan kualitas yang telah dimilikinya, baik dengan turut aktif mengikuti pelatihan-pelatihan atau terus melanjutkan pendidikan ke jenjang yang lebih tinggi, sehingga pembentukan sikap peduli lingkungan bukan lagi merupakan suatu kebetulan, melainkan ditanamkan secara sadar bahwa hal tersebut dilakukan semata-mata untuk pembentukan karakter sikap cinta peserta didik terhadap ling- kungan di sekitarnya. Begitupun dengan para orang tua dan anggota masyarakat yang berperan tinggi pula dalam penelitian ini dapat diharapkan lebih meningkatnya lagi bentuk perhatian terhadap sikap peduli lingkungan. 


\section{KESIMPULAN}

Secara umum dapat disimpulkan bahwa lingkungan sosial, baik itu dalam lingkungan keluarga, sekolah maupun lingkungan masyarakat, sama-sama memi- liki peranan penting serta tanggung jawab terhadap pembentukan karakter sikap peduli lingkungan peserta didik. Lingkungan sosial peserta didik yang menerapkan sikap cinta lingkungan dalam kehidupan sehari-hari, baik disadari ataupun tidak, dapat membentuk peserta didik menjadi pribadi yang memiliki kecintaan terhadap lingkungan sekitarnya. Kesimpulan secara khusus yang berkenaan dengan rumusan masalah dan hipotesis penelitian dapat dijabarkan sebagai berikut:

Pertama, lingkungan keluarga dapat memberikan pengaruh yang berarti terhadap pembentukan karakter sikap peduli lingkungan. Berdasarkan hasil penelitian, terlihat bahwa keluarga sudah menerapkan sikap kongkrit cinta terhadap lingkungan dalam kegiatan sehariharinya, mulai dari penumbuhan tata cara keagamaan di rumah, kemandirian dalam bersikap hubungan yang baik dan saling harga- menghargai sesama anggota keluarga lainnya, serta membiasakan diri untuk ramah terhadap lingkungan, seperti sudah menerapkan aturan membuang sampah pada tempatnya.

Kedua, lingkungan madrasah juga dapat memberikan peranan yang berarti dalam pembentukan sikap peduli ling- kungan peserta didik. Dari hasil penelitian menunjukan bahwa dalam lingkungan madrasah, guru yang memegang peranan penting terutama guru geografi dalam pembetukan sikap peduli lingkungan peserta didik. Guru yang sadar akan pentingnya peduli lingkungan, serta mampu memberikan kontribusi kepada peserta didik mengenani sikap peduli lingkungan dalam kegiatan sehari-hari. Namun dalam hasil penelitian dalam variabel lingkungan madrasah masih banyak beberapa faktor yang menjadikan ling- kungan madrasah tidak berperan tertinggi dalam penelitian ini, yaitu kebanyakan keadaan lingkungan madrasah di MAS Al-Islam yang kurang bersih dan kurang teratur dapat menyebabkan rendahnya peran lingkungan madrasah terhadap sikap peduli lingkungan peserta didik.

Ketiga lingkungan masyarakat/teman sebaya juga turut memberikan peranannya terhadap pembentukan karakter sikap peduli lingkungan peserta didik, bahkan memberikan peran tertinggi dalam pem- bentukan karakter sikap peduli lingkungan peserta didik, karena menurut hasil penelitian pada masa-masa remaja, peserta didik lebih banyak mendapatkan atau menghabiskan waktu dengan berinteraksi dengan lingkungan sosialnya/kelompok bermain, seperti contoh kebanyakan peserta didik selepas pulang dari madrasah mereka terbiasa untuk tidak langsung pulang kerumah masing-masing, melain- kan sering nya berkumpul bersama terlebih dahulu, sehingga dalam pembentukan karakter sikap peduli lingkungan peserta didik ini terbentuk dalam suatu kelompok sosial, baik di luar jam madrasah maupun di dalam jam sekolah. Peranan lingkungan masyarakat/teman sebaya memiliki kewajiban yang sama dalam membentuk karakter sikap peduli lingkungan peserta didik menjadi karakter yang peka terhadap lingkungan di sekitarnya.

\section{REFERENSI}

Akhadi, M. 2014. Isu Lingkungan Hidup. Graha Ilmu:Yogyakarta

Anwar, M. (2016). Lingkungan pendidikan dalam Al-quran. Jurnal Penelitian Ilmiah, Vol. 4. No. 2 Handayani, Sri. (2014). Kepedulian Lingkungan. Jumal Lingkungan. Vol. 17. No. 3.

Purwanto. (2009). Evaluasi hasil belajar. Surakarta. Pustaka belajar.

Ruhimat, dan Malik, Yakub. (2010).Memahami Bahaya Gempa dan Tsunami Melalui Pembelajaran Geografi. JurnalGea, Vol. 10, no. 10. Hal: 19.

Sala, Maria. (2011). Journal Geography. Department Of Geography, University Of Barcelona, Spain. [Online]. Tersedia: http//www.eolss.net/samplechapters/c01/E6-14.pdf. Diakses pada [6 Juni 2021]

Soeriaatmadja. 2003. Ilmu Lingkungan. ITB Press. Bandung 
Sumaatmadja, N. (1988). Studi Geografi: Suatu Pendekatan dan Analisa Keruangan. Cetakan kedua. Bandung: Alumni.

Suwartono. 2009. Pendidikan Kependudukan dan Lingkungan Hidup. UNS press. Surakarta 